\title{
Bacterial biosurfactant from Citrobacter freundii MG812314.1 as a bioremoval tool of heavy metals from wastewater
}

\author{
Eman Z. Gomaa ${ }^{1 *}$ and Rasha M. El-Meihy ${ }^{2,3}$
}

\begin{abstract}
Background: The problem of heavy metal contamination is a global issue, and the challenge is to develop methods to remove heavy metals from soil and water. Recently, biosurfactants are one of the compounds that provide an attractive eco-friendly alternative to the physicochemical process in alleviating the heavy metals.

Results: Sixty bacterial isolates were isolated from Al-Rahawy drain sediments and screened for biosurfactant production. Only 10 isolates were recoded as biosurfactant producers by the oil spreading and emulsifying assays in addition to the ability of biosurfactant on heavy metal removal in wastewater. The most potent isolate was identified using morphological, cultural, biochemical characteristics, antibiotics susceptibility, and $16 \mathrm{~s}$ rRNA technique as Citrobacter freundii MG812314.1.

Conclusions: The produced biosurfactant was found to be more effective in removing heavy metals from wastewater, viz 80, 67, 66, 55, 45, 44, and 41\% of aluminum, lead, zinc, cadmium, iron, copper, and manganese, respectively, under two inoculum potentials and two contact time. The interaction of heavy metals with biosurfactant was monitored using scanning electron microscope (SEM), energy dispersive X-ray spectra (EDX), and Fourier-transform infrared spectroscopy (FTIR) analyses.
\end{abstract}

Keywords: Heavy metals, Biosurfactant, Wastewater, Bioremediation, Citrobacter freundii

\section{Introduction}

Biosphere pollution due to heavy metals is a confused problem that causes negative effects on various environments. In some cases, the levels of heavy metals in all environments (air, water, and soil) are increasing to toxic levels with contributions from a wide variety of agricultural, industrial, and domestic sources.Metal-contaminated environments pose a risk on health and ecosystems. Moreover, the most abundant pollutants in waste water are heavy metals (Vijayanand and Divyashree 2015). Nowadays, the major problem that facing Egypt is the rise in the pollution level caused by the Nile's low water level, especially after completing the Ethiopia Dam building. Heavy metals that mainly derived from multiple anthropogenic sources are considered one of the important pollutants in the Nile River

\footnotetext{
* Correspondence: emann7778@yahoo.com

'Department of Biological and Geological Sciences, Faculty of Education, Ain

Shams University, Cairo, Egypt

Full list of author information is available at the end of the article
}

(Ezzat et al. 2012). These metals cause serious ecological problems because they are non-degradable and can bioaccumulate through the food chain (Goher et al. 2014).

There are many remediation techniques used to remove metals from soils and wastewater such as chemical precipitation, oxidation, adsorption immobilization, and phytoremediation (Patel and Vashi 2010). However, in general, these conventional treatment methods are expensive and not environmentally acceptable as they can themselves produce other waste disposal problems. Also, the low bioavailability of those metals in soils may limit the efficiency of their industrial applications (Sheng et al. 2008). Therefore, these disadvantages have prompted the search for effective, cheap, and eco-friendly alternatives.

Biosurfactants are one of the compounds that help in alleviating the bad influences of heavy metals (Singh and Cameotra 2013); there are reports on the use bacterial biosurfactant for remediation of heavy metals from aqueous solution (Ramani et al. 2012). Biosurfactants are 
surface-active degradable organic compounds produced by microorganisms (Bachmann et al. 2014). Generally, their structure includes two moieties, hydrophilic and hydrophobic, the first moiety consisting of amino acids, peptides, anions or cations, and mono-, di-, or polysaccharides, and the second moiety consisting of unsaturated or saturated fatty acids (Basak and Das 2014). Also, biosurfactants can be classified into several groups, viz. glycolipids, lipopeptides, lipopolysaccharides, phospholipids, and fatty acids/neutral lipids. Some of the advantages of biosurfactants over synthetic ones are cost-effectiveness, lower toxicity, higher biodegradability, better environmental compatibility, high selectivity and specific activity at extreme temperatures, $\mathrm{pH}$ and salinity, and the ability to be synthesized from renewable feed-stock (Adamu et al. 2015; Lazarkevich et al. 2015). Moreover, biosurfactants can be tailor-made to suit different applications by changing the production conditions or by modifying the genes involved in their biosynthesis (Thernmozhi et al. 2011).

This study aimed to isolate, screen, and identify of the biosurfactant-producing bacteria from different heavy metals which contaminated the water in Egypt, then optimize the biosurfactant production from the most potent isolate, and finally, examine the ability of the produced biosurfactant to remove heavy metals from wastewater.

\section{Materials and methods}

\section{Collected water sample locations}

Two contaminated water samples were collected during spring 2016 from two different locations along Al-Rahawy drain, Giza Governorate, Egypt (Fig. 1). Location no. (1) was downstream delta barrage-upstream $\mathrm{Al}$-Rahawy drain $\left(5 \mathrm{~km}\right.$ ) (temperature $23.0^{\circ} \mathrm{C}$ ). Location no. (2) was downstream Al-Rahawy drain-upstream Sabal drain (flows into Rosetta Branch from the west side about $9 \mathrm{~km}$ north of Delta Barrage) (temperature $25.0^{\circ} \mathrm{C}$ ). Samples were collected in sterile glass bottles and stored at $4{ }^{\circ} \mathrm{C}$ until use.

\section{Isolation of biosurfactant-producing bacteria}

One milliliter of each water sample was inoculated into $50 \mathrm{ml}$ nutrient broth (pH $7 \pm 0.2)$ (HIMEDIA Co., Germany). All flasks were incubated at $32 \pm 2{ }^{\circ} \mathrm{C}$ for $48 \mathrm{~h}$ in shaking incubator $(150 \mathrm{rpm} / \mathrm{min})$; then, $1 \mathrm{ml}$ of each culture was serially diluted up to $10^{-6}$. After that, $1 \mathrm{ml}$ of each dilution was transferred to sterile Petri dish containing the same solidified medium and incubated at 32 $\pm 2{ }^{\circ} \mathrm{C}$ for $48 \mathrm{~h}$. At the end of the incubation period, colonies were purified and maintained for further experiments (Sneha 2012).

\section{Screening of the isolated bacteria for biosurfactant production}

Each bacterial isolate was cultured in 100-ml Erlenmeyer flasks containing $50 \mathrm{ml}$ of nutrient broth medium, inoculated with $10 \%$ inoculum, and then, incubated at $32 \pm 2^{\circ}$ $\mathrm{C}$ for $72 \mathrm{~h}$. At the end of the incubation period, the cultures were centrifuged at $7000 \times g$ for $10 \mathrm{~min}$. The cell-free supernatant was analyzed for the presence of surface-active compounds by the following assays (Vijayanand and Divyashree 2015).

\section{Oil spreading assay}

Biosurfactant production was estimated using oil spreading assay as described by Youssef et al. (2004). One hundred microliters of crude sun flower oil was added to the surface of $50 \mathrm{ml}$ of distilled water in a Petri dish to form a thin oil layer. Then, $10 \mu \mathrm{l}$ of cell-free supernatant was gently placed on the center of the oil layer. The diameter of the clearing zone on the oil surface would be visualized under visible light and measured after $30 \mathrm{~s}$, which correlates to the surfactant activity, also known as oil displacement activity (Morikawa et al. 1993), using sodium dodecyl sulfate (SDS), a chemical surfactant compound, as control.
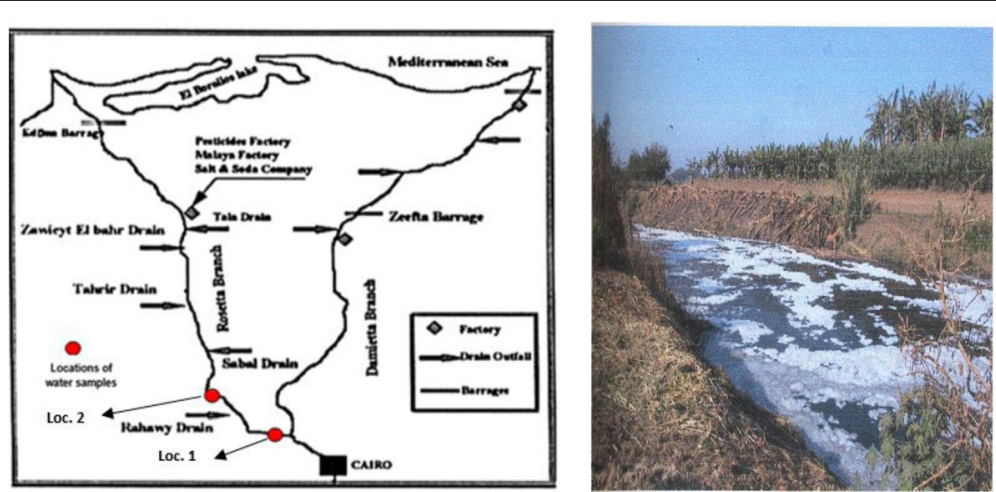

Fig. 1 Al-Rahawy drain, Giza Governorate, Egypt 


\section{Emulsifying assay}

Two milliliters of each cell-free supernatant was mixed with $2 \mathrm{ml}$ of toluene in clean glass tubes. The mixture was shaken vigorously for $2 \mathrm{~min}$ and then left to stand. Emulsification index (EI \%) and emulsification stability (ES \%) were measured in intervals up to $24 \mathrm{~h}$ using the following equations (Ariech and Guechi 2015).

$$
\begin{aligned}
& \text { EI }(\%)=\frac{\text { Emulsion height }(\mathrm{mm})}{\text { Total height }(\mathrm{mm})} \times 100 \\
& \text { ES }(\%)=\frac{\text { Emulsion height }(\mathrm{mm}) \text { after } 24 \mathrm{~h}}{\text { Emulsion height }(\mathrm{mm}) \text { at zero time }} \times 100
\end{aligned}
$$

\section{Effect of biosurfactant on heavy metal removal in wastewater}

The biosurfactants producing isolates which gave positive results in the previous screening assays were used in this experiment. One hundred milliliters of Erlenmeyer flasks containing $50 \mathrm{ml}$ of wastewater were treated with $5 \%$ cell-free supernatant of the selected isolates and incubated for $48 \mathrm{~h}$ under shaking conditions. Then, the residual concentrations of heavy metal were detected using plasma atomic emission spectrometry (ICP-AES), and the bioremoval activity was measured using the equation by Basak and Das (2014):

$$
\text { \%bioremoval activity }=\frac{C_{i}-C_{f}}{C_{i}} \times 100
$$

where

$C_{i}$ is the initial concentration of heavy metal in wastewater before treatment

$C_{f}$ is the final concentration of heavy metal in wastewater treated with bacterial supernatant

\section{Bacterial identification}

\section{Morphological, cultural, and biochemical characterization}

A light microscope was used to check for Gram stain reaction, shape, sporulation, and motility procedures, while hanging drop method was used to determine the motility of the most biosurfactant-producing bacteria (Bertrand et al. 2001). Spore formation was determined according to Harrigan and MacCance (1976). The cultural characteristics were recorded as colony morphology, i.e., color, shape, size, nature of the colony, and pigmentation, according to the method described by Hucker and Conn (1923). Additionally, biochemical characteristics (oxidase, catalase, and amylase enzymes, indole, methyl red, and Voges Proskauer tests as well as sugar fermentation) were estimated as according to the key of Bergey's Manual of Systematic Bacteriology (Janda et al. 1994).

\section{Antibiotics susceptibility test}

Susceptibility test of the potent biosurfactant-producing isolate was carried out using disk diffusion method (Matuschek et al. 2014). The antibiotics used were amphenicols (chloramphenicol), tetracyclines (tetracycline), quinolones (nalidixic acid), polymyxins (polymyxin b), macrolides (erythromycin $15 \mathrm{mg}$ ), and glycopeptide (vancomycin $500 \mathrm{mg}$ ).

\section{DNA and phylogenetic analysis}

The potent biosurfactant-producing bacterial isolate was identified by $16 \mathrm{~S}$ rRNA sequencing analysis according to the method described by Abdel-Rahman et al. (2017). Sequence analysis was performed using Basic Local Alignment Search Tool for Nucleotides (BLASTN) with sequences at the National Center for Biotechnology Information (NCBI), USA, database.

\section{Optimization of biosurfactant production}

In addition to nutrient broth medium, three broth media, viz. mineral salt with glucose (MSG), LB, and peptone yeast extract glucose (PYG), were used in this experiment. All these media were obtained from HIMEDIA Co., Germany. Moreover, four incubation periods $\left(3,4,5\right.$, and 6 days) and three inoculum potentials $10^{6}$ $\mathrm{CFU} / \mathrm{ml}(5,10$, and $15 \%)$ were examined according to Ibrahim (2018) and Basak and Das (2014), respectively.

\section{Biosurfactant extraction and partial purification}

Biosurfactants were extracted by adjusting the $\mathrm{pH}$ of cell-free supernatant to 2.0 using $6 \mathrm{~N} \mathrm{HCl}$ and keeping it at $4{ }^{\circ} \mathrm{C}$ overnight. The precipitate thus obtained was pelleted by centrifugation at $7000 \times g$ for $20 \mathrm{~min}$ and dried (Suganya 2013). For partial purification, the crude surfactant was dissolved in distilled water at $\mathrm{pH} 7.0$ and dried at $60^{\circ} \mathrm{C}$. The dry product was extracted with mixture of chloroform:methanol (65:15) and then filtered, and the solvent was evaporated.

\section{Factors affecting the removal of heavy metals from wastewater}

Two hundred milliliters of Erlenmeyer flasks containing $100 \mathrm{ml}$ of wastewater were treated with the produced biosurfactant at various concentrations, viz. 5 and $10 \%$ $(w / v)$, and incubated at $32 \pm 2{ }^{\circ} \mathrm{C}$ for two different periods, namely 3 and 6 days. Then, seven heavy metal, namely aluminum $\left(\mathrm{Al}^{2+}\right)$, cadmium $\left(\mathrm{Cd}^{2+}\right)$, copper $\left(\mathrm{Cu}^{2}\right.$ $\left.{ }^{+}\right)$, iron $\left(\mathrm{Fe}^{2+}\right)$, lead $\left(\mathrm{Pb}^{2+}\right)$, manganese $\left(\mathrm{Mn}^{2+}\right)$, and zinc $\left(\mathrm{Zn}^{2+}\right)$, concentrations were determined using plasma atomic emission spectrometry (ICP-AES) as described by Becker (2005). Wastewater without any amendments was used as control. The bioremoval activity was measured as the equation previously mentioned. 


\section{Metal chelating activity}

In this experiment, three assays using scanning electron microscope (SEM), energy dispersive X-ray spectra (EDX), and Fourier-transform infrared spectroscopy (FTIR) analyses were done to study the ability of the produced biosurfactant to chelate heavy metals from wastewater as described by Basak and Das (2014). The morphology of the native biosurfactant and that interacted with heavy metals was investigated. After completely dried and grounded into powder form, samples were gold coated using SPI-Module sputter coater and examined under scanning electron microscope (JEOL, JSM-5500 LV) at $20 \mathrm{kV}$. EDX analysis of the samples was performed using X-ray microanalyzer (Module oxford 6587 INCA $x$-sight) attached to SEM at the Regional Center of Mycology and Biotechnology, Cairo, Egypt. Additionally, FTIR was conducted using Perkin Elmer spectrophotometer (Jasco-6100, Japan) to show the differences between native and heavy metals interacted biosurfactant. The dried materials were ground with $\mathrm{KBr}$ pellets and measured in the wavelength range 4000 to $500 \mathrm{~cm}^{-1}$.

\section{Statistical analysis}

Analysis of variance in one- and two-way ANOVA was carried out using the SAS procedure guide (SAS 2004). Significant differences among means were tested using the Duncan multiple range test (Duncan 1955).

\section{Results}

\section{Isolation of biosurfactant-producing bacteria}

In this experiment, two contaminated water samples were collected from two different locations along Al-Rahawy drain, Giza Governorate, Egypt. A total of 60 bacterial isolates were recovered on nutrient agar medium. Twenty-three isolates (38\%) were isolated from location (1) upstream Al-Rahawy drain sediment (BS1-BS23), and 37 isolates (62\%) were isolated from location (2) downstream Al-Rahawy drain sediment (BS24-BS60) (Fig. 2).

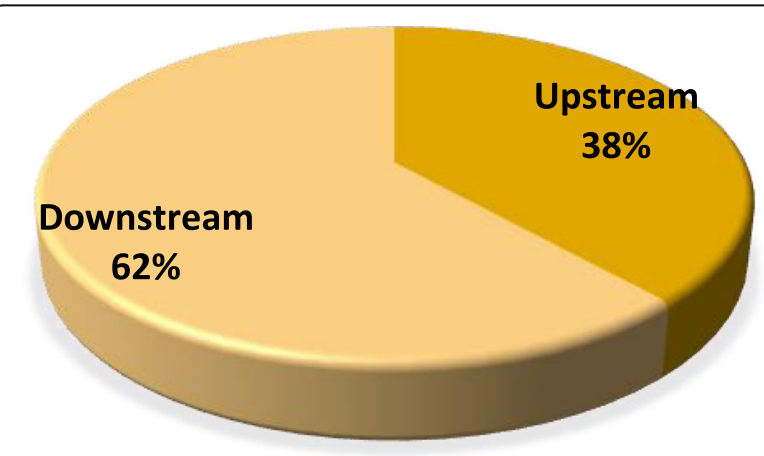

Fig. 2 Percentage of isolated bacteria from two contaminated water samples along Al-Rahawy drain, Giza Governorate, Egypt

\section{Screening of the isolated bacteria for biosurfactant} production

\section{Oil spreading assay}

The results in Table 1 showed that among all 60 tested bacterial isolates, only 10 isolates (BS3, BS9, BS12, BS17, BS33, BS34, BS37, BS42, BS43, BS55) were able to displace oil and form a clear zone. This may be due to the presence of biosurfactant which degrade the oil and form a clear zone. The diameter of clear zone ranged between 7 and $30 \mathrm{~mm}$. The isolate BS37 showed higher zone of displacement compared to other isolates (Fig. 3), while the least zone of displacement was found by the isolate BS55.

\section{Emulsifying assay}

The results recorded in Table 1 and illustrated by Fig. 4 showed that the isolate BS37 showed the maximum emulsification index (89.0\%) followed by the isolate BS3 (70.0\%) and the least activity was shown by the isolate BS55 (31.4\%). Also, the data proved that all tested isolates showed relative emulsification stability after $24 \mathrm{~h}$. The isolate BS37 gave higher emulsion stability (90.9\%) compared to other isolates.

\section{Effect of biosurfactants on heavy metal removal in wastewater}

Data presented in Table 2 indicated that all ten isolates were able to decrease all estimated heavy metals in wastewater $\mathrm{Al}^{2+}, \mathrm{Cd}^{2+}, \mathrm{Cu}^{2+}, \mathrm{Fe}^{2+}, \mathrm{Pb}^{2+}, \mathrm{Mn}^{2+}$, and $\mathrm{Zn}^{2}$ $\left.{ }^{+}\right)$with various percentages. Generally, $\mathrm{Al}^{2+}$ and $\mathrm{Cu}^{2+}$ were considered as the highest and the lowest removed heavy metals by all tested isolates, respectively. Moreover, the biosurfactant produced by the isolate BS37 was able to remove the highest amounts of all tested heavy metals from wastewater. Therefore, this isolate was selected for further experiments.

\section{Identification of the most potent bacterial isolate}

Bacterial isolate BS37 showed the highest biosurfactant production and exhibited the greatest heavy metal removal efficiency which was identified as follows:

\section{Morphological and biochemical characterization}

The isolate BS37 was straight short rods, Gram-negative, motile, and non-spore forming. Also, it was a facultative anaerobe, and its colonies were smooth, mucoid, and light gray in color but do not able to produce soluble pigments in broth medium (Table 3).

\section{Phenotypic characterization}

The characteristics of the isolate BS37 presented in Table 3 showed that it is not able to grow on nitrogen-free medium, produces hydrogen cyanide $\left(\mathrm{H}_{2} \mathrm{~S}\right)$, and is catalase-positive and oxidase-negative. It utilized citrate as 
Table 1 Screening of the isolated bacteria for biosurfactant production

\begin{tabular}{|c|c|c|c|c|c|c|c|c|c|c|c|c|}
\hline \multirow[t]{2}{*}{ Assays } & \multirow[t]{2}{*}{ SDS } & \multicolumn{10}{|c|}{ Bacterial isolates } & \multirow[t]{2}{*}{ MSE } \\
\hline & & $\mathrm{BS3}$ & BS9 & BS12 & BS17 & BS33 & BS34 & BS37 & BS42 & $\mathrm{BS} 43$ & $\mathrm{BS} 55$ & \\
\hline Oil spreading (mm) & $25^{\mathrm{ab}}$ & $20^{\mathrm{bc}}$ & $21^{\mathrm{bc}}$ & $11^{\mathrm{ef}}$ & $12^{\mathrm{ef}}$ & $17^{\text {cde }}$ & $18^{\mathrm{cd}}$ & $30^{\mathrm{a}}$ & $9.0^{f}$ & $11^{\mathrm{ef}}$ & $7.0^{f}$ & 1.81 \\
\hline El \% & $69.1^{\mathrm{b}}$ & $70.0^{\mathrm{b}}$ & $62.1^{c}$ & $59.1^{c d}$ & $32.1^{f}$ & $41.8^{\mathrm{e}}$ & $41.8^{\mathrm{e}}$ & $89.0^{\mathrm{a}}$ & $33.5^{f}$ & $55.6^{d}$ & $31.4^{f}$ & 1.0 \\
\hline ES $\%$ & $71.4^{\mathrm{bc}}$ & $71.4^{\mathrm{bc}}$ & $70.9^{b c}$ & $60.9^{e}$ & $71.0^{\mathrm{bc}}$ & $59.8^{e}$ & $69.4^{c}$ & $90.9^{\mathrm{a}}$ & $65.7^{d}$ & $64.7^{d}$ & $73.2^{\mathrm{b}}$ & 1.0 \\
\hline
\end{tabular}

Mean having similar letters in each column are not significantly different $(P<0.05)$

El emulsification index, ES emulsification stability

a sole carbon source and is positive in indole and methyl red tests, but negative in Voges-Proskauer test. Additionally, it was able to utilize glucose, xylose, arabinose, maltose, and mannitol as sole carbon source and the acid derived from them which caused indicator color change, but do not able to use lactose.

\section{Antibiotic susceptibility test}

Antibiotic susceptibility patterns of the obtained BS37 isolate demonstrated a susceptibility profile characteristic (Table 3). The isolate was resistant to polymyxin b and erythromycin. It remained susceptible to chloramphenicol, tetracycline, nalidixic acid, and vancomycin.

\section{DNA and phylogenetic analysis}

Amplification of 16S rRNA of the isolate BS37 and its sequencing were carried out, and the BLAST analysis of the complete sequences of $16 \mathrm{~S}$ rRNA revealed the isolate to be Citrobacter freundii (GenBank accession No. MG812314.1). Distribution of the various strains on the phylogenetic tree showed that the isolate was closely related to the reference standard strains (Fig. 5a, b). The bacterial classification is phylum, Proteobacteria; class, Gammaproteobacteria; order, Enterobacteriales; family, Enterobacteriaceae; genus, Citrobacter.

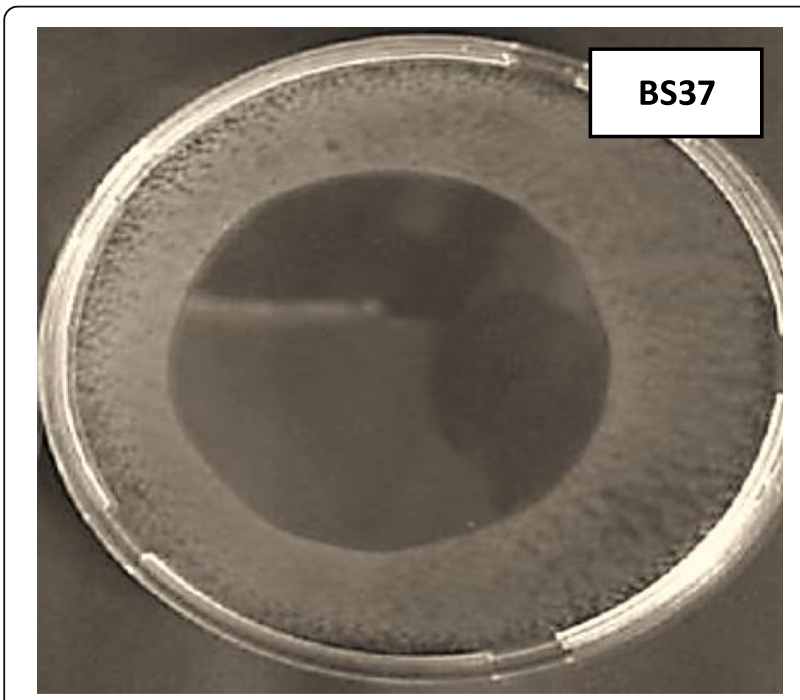

Fig. 3 Oil spreading assay of bacterial isolate BS37

\section{Optimization of biosurfactant production by $C$. freundii MG812314.1}

Citrobacter freundii could produce biosurfactant using all the tested media. It was observed that nutrient broth medium yielded the maximum biosurfactant production by $C$. freundii MG812314.1, and the emulsification index reached $89 \%$ (Fig. 6). In contrast, the lowest biosurfactant production $(\mathrm{EI}=5 \%)$ was recorded when $C$. freundii MG812314.1 is cultured on LB medium. Regarding the interaction between the inoculum potential (\%) and the incubation period (days) on biosurfactants production by C. freundii MG812314.1., data graphically illustrated by Fig. 7a, b, and c showed that inoculum potential of $10 \%$ and incubation period of 4 days were found to yield maximal amount of biosurfactant $(E I=95.8 \%)$.

\section{Factors affecting the removal of heavy metals from wastewater}

Data presented in Table 4 indicated that higher removal of heavy metals was recorded when wastewater was treated with biosurfactant at $10 \%$ than $5 \%$. Results also showed higher removal efficiency with increasing the contact time when wastewater was treated with $5 \%$ biosurfactant. In contrast, when treated with $10 \%$, the removal efficiency was decreased with the increasing of the contact time. Generally, the highest removal of all heavy metals was observed when wastewater was treated with $10 \%$ and incubated for 3 days. Interestingly, the highest and the lowest removed metals from wastewater by biosurfactant were $\mathrm{Al}^{2+}$ and $\mathrm{Cu}^{2+}$, respectively. This trend of results was true when wastewater was treated with any biosurfactant concentration and incubated for any contact time. This result agrees with the results in

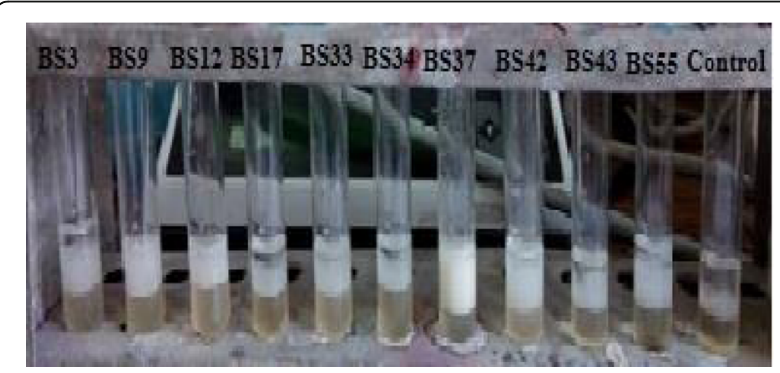

Fig. 4 Emulsifying assay of the tested bacterial isolates 
Table 2 Efficiency of biosurfactants of the ten selected isolates to remove heavy metals from wastewater

\begin{tabular}{|c|c|c|c|c|c|c|c|c|c|c|c|}
\hline \multirow[t]{3}{*}{ Heavy meals } & \multicolumn{10}{|c|}{ Biosurfactant-producing bacterial isolates } & \multirow{3}{*}{ MSE } \\
\hline & $\mathrm{BS3}$ & BS9 & $\mathrm{BS} 12$ & BS17 & BS33 & BS34 & $\mathrm{BS} 37$ & BS42 & BS43 & $\mathrm{BS} 55$ & \\
\hline & \multicolumn{10}{|c|}{ Heavy metals removal (\%) } & \\
\hline Aluminum $\left(\mathrm{Al}^{2+}\right)$ & $82.0^{\mathrm{bc}}$ & $78.5^{d}$ & $83.3^{b}$ & $79.8^{\mathrm{cd}}$ & $83.4^{\mathrm{b}}$ & $83.4^{\mathrm{b}}$ & $87.4^{\mathrm{a}}$ & $81.5^{\mathrm{bcd}}$ & $81.3^{\mathrm{bcd}}$ & $82.2^{\mathrm{bc}}$ & 0.98 \\
\hline Cadmium $\left(\mathrm{Cd}^{2+}\right)$ & $13.9^{f}$ & $19.9^{\mathrm{de}}$ & $30.0^{\mathrm{b}}$ & $20.9^{d}$ & $19.9^{\mathrm{de}}$ & $19.5^{\mathrm{de}}$ & $39.9^{\mathrm{a}}$ & $22.7^{c}$ & $18.9^{e}$ & $24.3^{c}$ & 0.56 \\
\hline Copper $\left(\mathrm{Cu}^{2+}\right)$ & $10.3^{\text {de }}$ & $11.0^{\mathrm{bc}}$ & $8.10^{9}$ & $10.7^{\mathrm{cd}}$ & $9.80^{\text {ef }}$ & $2.10^{\mathrm{h}}$ & $19.2^{\mathrm{a}}$ & $11.3^{\mathrm{b}}$ & $9.70^{f}$ & $9.30^{f}$ & 0.19 \\
\hline Iron $\left(\mathrm{Fe}^{2+}\right)$ & $19.3^{f}$ & $21.3^{d}$ & $31.3^{\mathrm{b}}$ & $24.3^{c}$ & $18.3^{9}$ & $11.3^{\mathrm{h}}$ & $33.8^{\mathrm{a}}$ & $20.3^{e}$ & $11.0^{\mathrm{h}}$ & $21.1^{d}$ & 0.25 \\
\hline Lead $\left(\mathrm{Pb}^{2+}\right)$ & $51.0^{\mathrm{b}}$ & $6.70^{j}$ & $23.8^{h}$ & $41.7^{d}$ & $32.5^{f}$ & $46.4^{c}$ & $56.8^{\mathrm{a}}$ & $36.9^{e}$ & $29.2^{9}$ & $16.4^{i}$ & 0.29 \\
\hline Manganese $\left(\mathrm{Mn}^{2+}\right)$ & $15.8^{e}$ & $17.9^{\mathrm{d}}$ & $20.8^{b}$ & $19.3^{c}$ & $11.5^{f}$ & $15.0^{\mathrm{e}}$ & $25.3^{\mathrm{a}}$ & $20.1^{b c}$ & ND & ND & 0.27 \\
\hline $\operatorname{Zinc}\left(Z n^{2+}\right)$ & $43.1^{c}$ & $20.5^{i}$ & $28.7^{9}$ & $41.8^{d}$ & $45.1^{\mathrm{b}}$ & $43.2^{c}$ & $49.2^{\mathrm{a}}$ & $38.0^{\mathrm{e}}$ & $33.5^{f}$ & $28.0^{h}$ & 0.20 \\
\hline
\end{tabular}

Mean having similar letters in each row are not significantly different $(P<0.05)$

Table 2 which proved that $\mathrm{Al}^{2+}$ was removed more than other metals by all tested isolates.

\section{Metal chelating activity \\ Scanning electron microscopy}

SEM images showed the morphology of native biosurfactant (Fig. 8a) and the sequestered heavy metals onto biosurfactant (Fig. 8b). The spherical nodules in SEM image (b) confirmed the anchoring of heavy metal ions with biosurfactant molecule.

\section{EDX analysis}

EDX of native biosurfactant (Fig. 9a) and heavy metals interacted biosurfactant (Fig. 9b) showed that there were constant metals in either native or interacted biosurfactant, viz. $\mathrm{O}, \mathrm{Na}, \mathrm{Al}, \mathrm{P}, \mathrm{S}$, and $\mathrm{Cl}$, whereas $\mathrm{Fe}^{2+}, \mathrm{Cu}^{2+}, \mathrm{Zn}^{2+}$, and $\mathrm{Pb}^{2+}$ appeared in interacted biosurfactant with wastewater only.

\section{FTIR analysis}

The FTIR spectrum of native biosurfactant (Fig. 10a) showed the presence of $\mathrm{O}-\mathrm{H}$ stretching at $3444.21 \mathrm{~cm}^{-1}$. The absorption band noted at $1630.30 \mathrm{~cm}^{-1}$ was due to carbonyl stretching of $\mathrm{C}=\mathrm{O}$ group. A band at 1452.56 $\mathrm{cm}^{-1}$ indicated $\mathrm{C}-\mathrm{O}$ stretch. FTIR spectrum of biosurfactant interacted with heavy metals present in wastewater showed that the recorded peaks at 3444.21, 1630.30, and $1452.56 \mathrm{~cm}^{-1}$ were shifted respectively to 3446.12 , 1635.82 , and $1456.87 \mathrm{~cm}^{-1}$. Also, new bands appeared at 2842.11 and $1540.54 \mathrm{~cm}^{-1}$ (Fig. 10b).

\section{Discussion}

Biosurfactants are amphiphilic nature compounds with massive diversity and broad spectrum of functions and environmental applications which make them good bio-products. Contaminated soil and water are known as continuous sources of different microorganisms which are able to emulsify and solubilize hydrophobic compounds and have advantages over their competitors;

Table 3 Morphological, cultural, biochemical characteristics and antibiotics susceptibility of the highest BS-producing bacterial isolate (BS37)

\begin{tabular}{|c|c|c|c|c|}
\hline \multicolumn{2}{|l|}{ Characteristics } & SB37 & Characteristics & SB37 \\
\hline \multirow{5}{*}{\multicolumn{2}{|c|}{$\begin{array}{l}\text { Shape } \\
\text { Gram staining } \\
\text { Motility } \\
\text { Respiration } \\
\text { Spore formation }\end{array}$}} & Short rod & Grow on nitrogen free medium & - \\
\hline & & Negative & $\mathrm{H}_{2} \mathrm{~S}$ production & + \\
\hline & & Motile & Catalase production & + \\
\hline & & Facultatively anaerobic & Oxidase production & - \\
\hline & & Non-spore forming & Citrate utilization & + \\
\hline Pigmentation & of colony & Light gray & Indole production & + \\
\hline (Colonver & of medium & Smooth and mucoid & V.P. test & - \\
\hline Colony & & Smooth and mucoid & Methyl Red & \\
\hline
\end{tabular}

\begin{tabular}{l|cccccc}
\hline $\begin{array}{l}\text { Carbon source } \\
\text { and acid derived }\end{array}$ & Glucose & Xylose & Arabinose & Maltose & Mannitol & lactose \\
\cline { 2 - 7 } & + & + & + & + & + & - \\
$\begin{array}{l}\text { Antibiotic } \\
\text { susceptibility }\end{array}$ & Chlora. & Tetra. & Nalidixic & Polymyx. & Erythro. & Vanco. \\
\cline { 2 - 7 } & $\mathrm{S}$ & $\mathrm{S}$ & $\mathrm{S}$ & $\mathrm{R}$ & $\mathrm{R}$ & $\mathrm{S}$
\end{tabular}




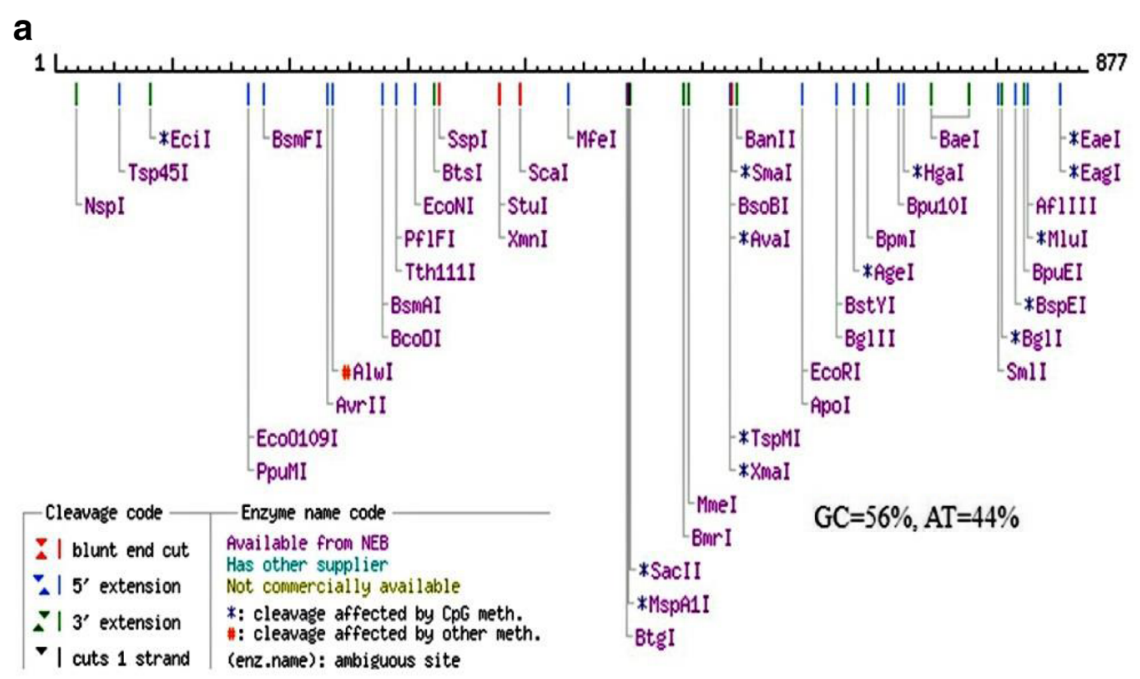

\section{b}

Citrobacter freundii (KF156749.1) Citrobacter braakii (KT764987.1)

Citrobacter braakii (HM172501.1)

Citrobacter braakii (CP022049.1)

Citrobacter freundï (LN998087.1)

Citrobacter youngae (KT440881.1)

Citrobacter sp. (KR189737.1)

Citrobacter freundii (JQ231164.1)

Citrobacter freundii (KF145194.1)

Citrobacter freundii (JQ231157.1)

Citrobacter sp. (JF749223.1)

Citrobacter freundiï (KF245926.1) ratio 99\%

Citrobacter freundii current study (MG812314.1)

Citrobacter freundii (CP024898.1)

Fig. 5 a Restriction map of the partial sequence of 165 rRNA gene of interest with available commercially restriction enzymes. $\mathbf{b}$ Phylogenetic tree showing interrelationships of isolate (BS37) based on 16S rRNA sequences

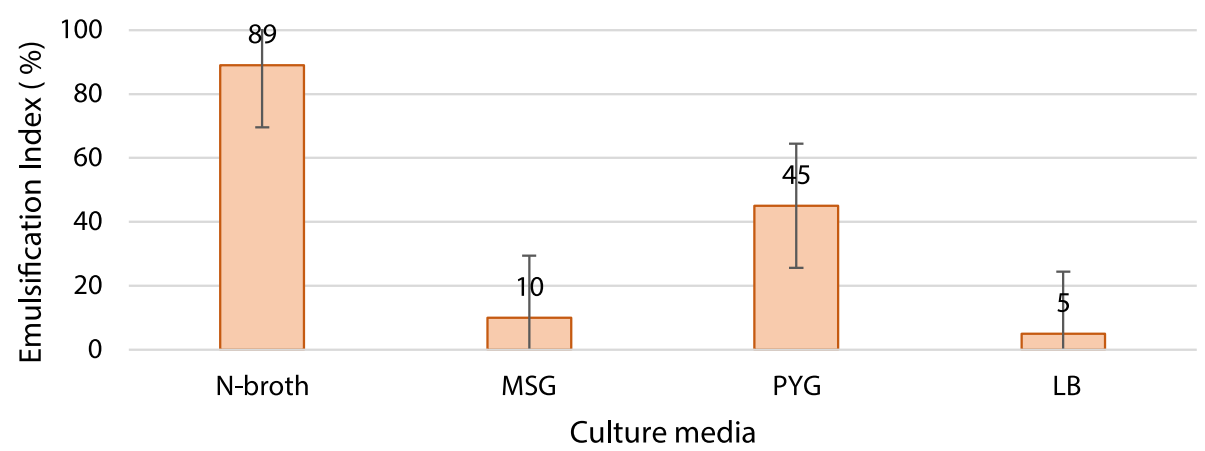

Fig. 6 Biosurfactant production by C. freundii MG812314.1 using different media 


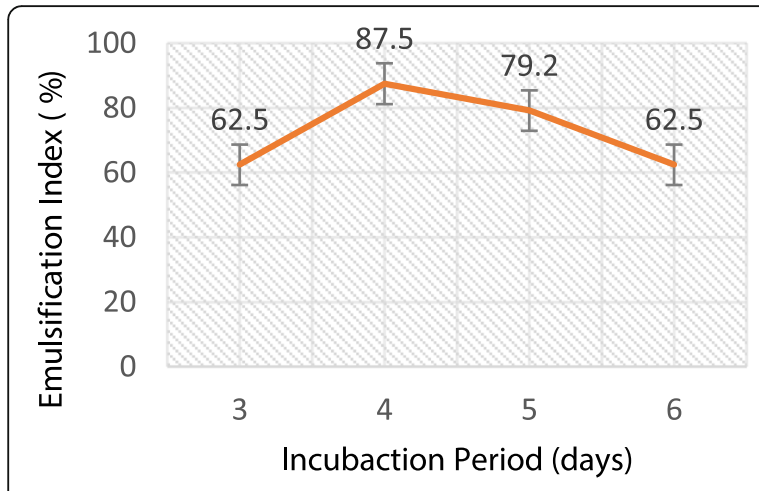

a With inoculum potential $5 \%$

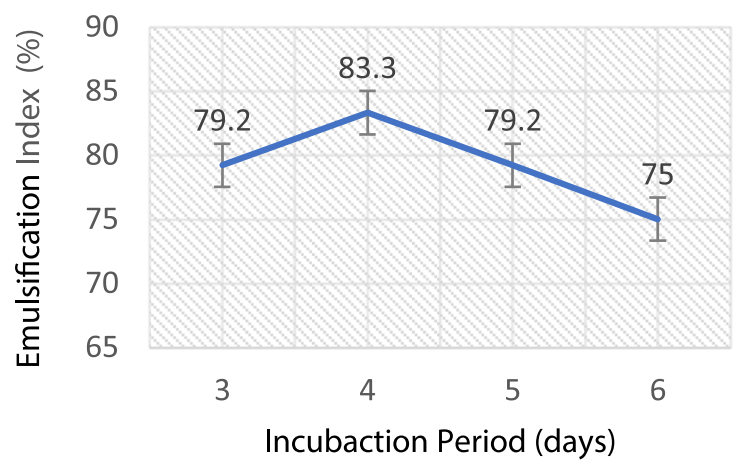

c With inoculum potential $15 \%$

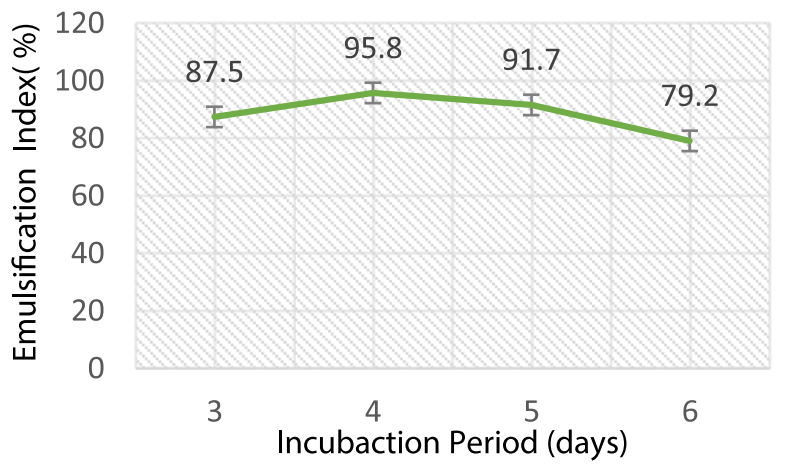

b With inoculum potential $10 \%$

Fig. 7 a-c Effect of interaction between the inoculum potential and the incubation period on biosurfactants production by C. freundii MG812314.1. a Inoculum potential 5\%. b Inoculum potential 10\%. c Inoculum potential 15\%

collecting samples from these environments provides a rich source of microorganisms with desirable properties. In this study, pure biosurfactant-producing bacterial isolates were recovered from contaminated water samples collected from two locations along Al-Rahawy drain, Giza Governorate, Egypt, and it was clear that larger number of isolates was obtained from downstream than upstream Al-Rahawy drain water samples. This result was logical and may be attributed to location no. 1 receiving pollutants from about 66 drains for $1000 \mathrm{~km}$

Table 4 Factors affecting removal of heavy metals from wastewater

\begin{tabular}{|c|c|c|c|c|c|c|c|c|}
\hline \multirow{2}{*}{$\begin{array}{l}\text { Biosurfactant } \\
\text { amount (\%) }\end{array}$} & \multirow{2}{*}{$\begin{array}{l}\text { Contact } \\
\text { time } \\
\text { (day) }\end{array}$} & \multicolumn{7}{|c|}{ Heavy metals removal (\%) } \\
\hline & & $\overline{\mathrm{Al}^{2+}}$ & $\mathrm{Cd}^{2+}$ & $\mathrm{Cu}^{2+}$ & $\mathrm{Fe}^{2+}$ & $\mathrm{Pb}^{2+}$ & $\mathrm{Mn}^{2+}$ & $\mathrm{Zn}^{2+}$ \\
\hline \multirow[t]{2}{*}{5} & 3 & $47.0^{b}$ & $25.0^{c}$ & $50.0^{c}$ & $30.0^{\mathrm{b}}$ & $20.0^{c}$ & $30.0^{c}$ & $55.0^{c}$ \\
\hline & 6 & $50.0^{b}$ & $30.0^{b}$ & $52.0^{c}$ & $35.0^{\mathrm{b}}$ & $23.0^{c}$ & $40.0^{b}$ & $62.0^{\mathrm{b}}$ \\
\hline \multirow[t]{2}{*}{10} & 3 & $66.0^{\mathrm{a}}$ & $41.0^{\mathrm{a}}$ & $67.0^{\mathrm{a}}$ & $45.0^{\mathrm{a}}$ & $44.0^{\mathrm{a}}$ & 55.0 & $80.0^{\mathrm{a}}$ \\
\hline & 6 & $54.0^{\mathrm{b}}$ & $39.0^{\mathrm{a}}$ & $61.0^{\mathrm{b}}$ & $33.0^{\mathrm{b}}$ & $37.0^{\mathrm{b}}$ & 53.0 & $77.0^{a}$ \\
\hline MSE & & 2.17 & 0.91 & 0.91 & 2.34 & 1.77 & 1.47 & 1.38 \\
\hline
\end{tabular}

Mean having similar letters in each column are not significantly different $(P<0.05)$ passing through governorates from Aswan to Cairo, but with different degrees of pollution, whereas location no. (2) is extended after Al-Rahawy drain and carries the combined discharge from the agricultural drainage system and the two sewerage pump stations (Zenein and Abo-Rawwash) that flows into Rosetta Branch from the west side about $9 \mathrm{~km}$ north of Delta Barrage, in addition to the industrial facilities that drainage in Al-Rahawy drain or in its branched drains. It is worth mentioning that due to the steady population increase and the large urban expansions in the areas served by these two stations, the quantities of the entered sewage increased up to $180 \%$ of its capacity which led to the conversion of this sewage water without treatment to the drain. Also, untreated sewage from the group of population blocs and parcels spread throughout the drain and its branches in Giza Governorate (El Bedawy 2014; Egypt State of Environment 2015; Wolters et al. 2016). In the same trend, Elazzazy et al. (2015) isolated 23 biosurfactant-producing bacterial colonies from soil and sea water samples, which were collected from Jeddah region, Saudi Arabia. 

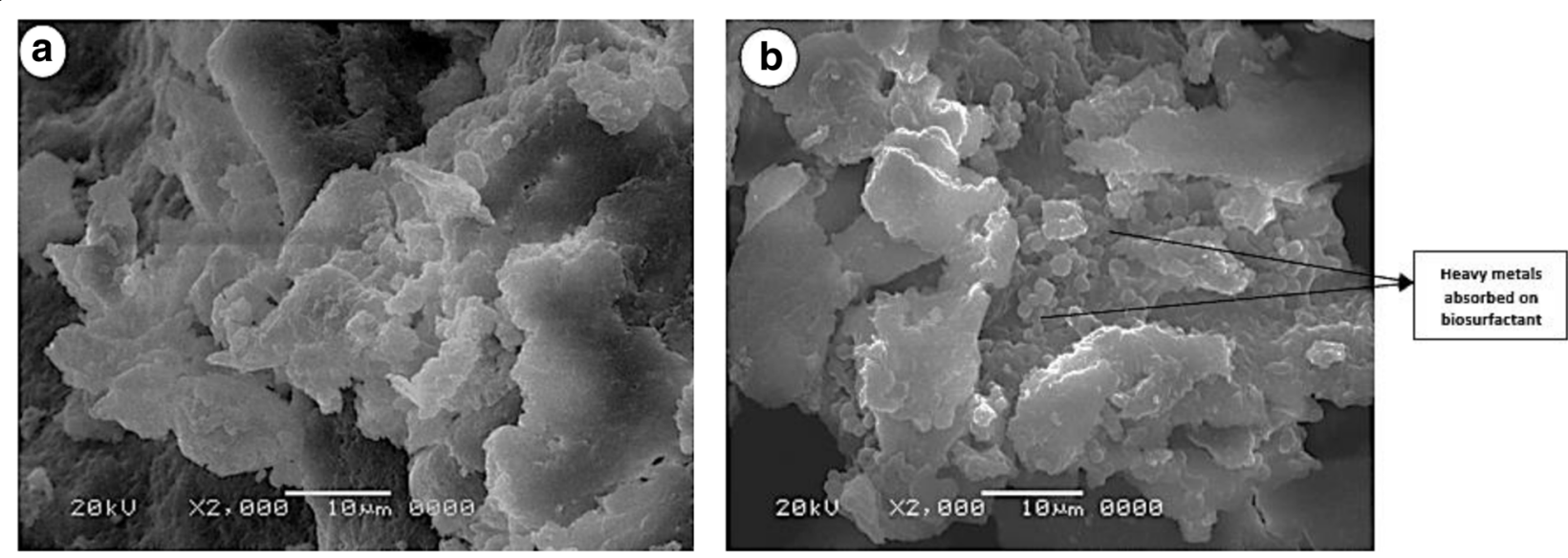

Fig. 8 SEM images of a native biosurfactant and $\mathbf{b}$ biosurfactant interacted with wastewater

The screening for biosurfactant production was carried out using two techniques, oil spreading and emulsion activity, as reported by Satpute et al. (2008) who affirmed that more than one screening method should be used in the primary screening for the biosurfactant producers. Further, these methods have many advantages, viz. simplicity, low cost, and quick application. Supplement to this trend, many researchers used other methods in this primary screening such as the cultivation of bacteria on blood agar medium and the drop collapse method as a sensitive and easy method; dark blue halo zone in the methylene blue agar plate supplemented with CTAB confirmed the presence of an anionic biosurfactant and surface tension decrease (Elazzazy et al. 2015). The oil displace test is indicative of surface wetting activity (Youssef et al. 2004) which depends on a drop of the bacterial supernatant containing a biosurfactant which collapses and spreads over the oily surface. There is a direct relation between the diameter of oil spread and biosurfactant's concentration, and in contrast, the bacterial supernatant lacking biosurfactant cannot spread oil due to the hydrophobicity of the oil surface that causes aggregation of droplets (Gautam and Tyagi 2006). The results of our experiment indicated that the selected 10 isolates were able to spread oil and form a clear zone; then, these isolates were exposed to complementary screening which included surface emulsion activity measurements. This emulsification index is one of the important methods to support the selection of potent biosurfactant producers. In this regard, these 10 isolates were also tested for their abilities for emulsification of toluene to confirm their biosurfactant production as reported by Chen et al. (2007) who evaluate biosurfactant-producing microbes using emulsification capacity as a simple screening method. Also, Vijayanand and Divyashree (2015) recorded the emulsification index of six bacterial strains ranged between 62.3 and $92.4 \%$.
Additionally, Ariech and Guechi (2015) reported that between the six strains, only two gave emulsification stability after $24 \mathrm{~h}$ with 80 and $54.4 \%$. The emulsifier action depends on the affinity of bioemulsifier for hydrocarbon molecules which include a direct interaction with hydrocarbon itself rather than its effect on surface tension of the environment (Amiriyan et al. 2006). Extracellular metabolites produced by bacteria, viz. biosurfactants and siderophores, can precipitate heavy metals (Rajkumar et al. 2010); these compounds efficiently restrict heavy metals and detoxify them by complex formation or by forming an effective barrier surrounding the cell (Pulsawat et al. 2003). The application of biosurfactants in the remediation of heavy metals targeted the removal of these ions by chemical interactions between the amphiphiles and the metal ions. This application seems to be more environmentally compatible and more economical than using modified clay complexes or metal chelators.

The removal of heavy metal contaminants from the environment is one of the potential areas in which the usefulness of biosurfactants has not been thoroughly explored (Luna et al. 2016). In this regard, the efficiency of the biosurfactants produced by the selected isolates to remove heavy metals from wastewater was studied. Our results generally indicated that $\mathrm{Al}^{2+}$ and $\mathrm{Cu}^{2+}$ were considered as the highest and the lowest removed heavy metals by all tested isolates, respectively. Moreover, the biosurfactant produced by isolate BS37 was able to remove the highest amounts of all tested heavy metals from wastewater. The bacterial biosurfactants can capture the metal ions through electrostatic interactions or complexation. The molecular nature of biosurfactants offers the possibility of interaction with the metals in solution, aiding in their subsequent removal and/or recovery. The anionic biosurfactants create complexes with metals in a nonionic form by ionic bonds. These 


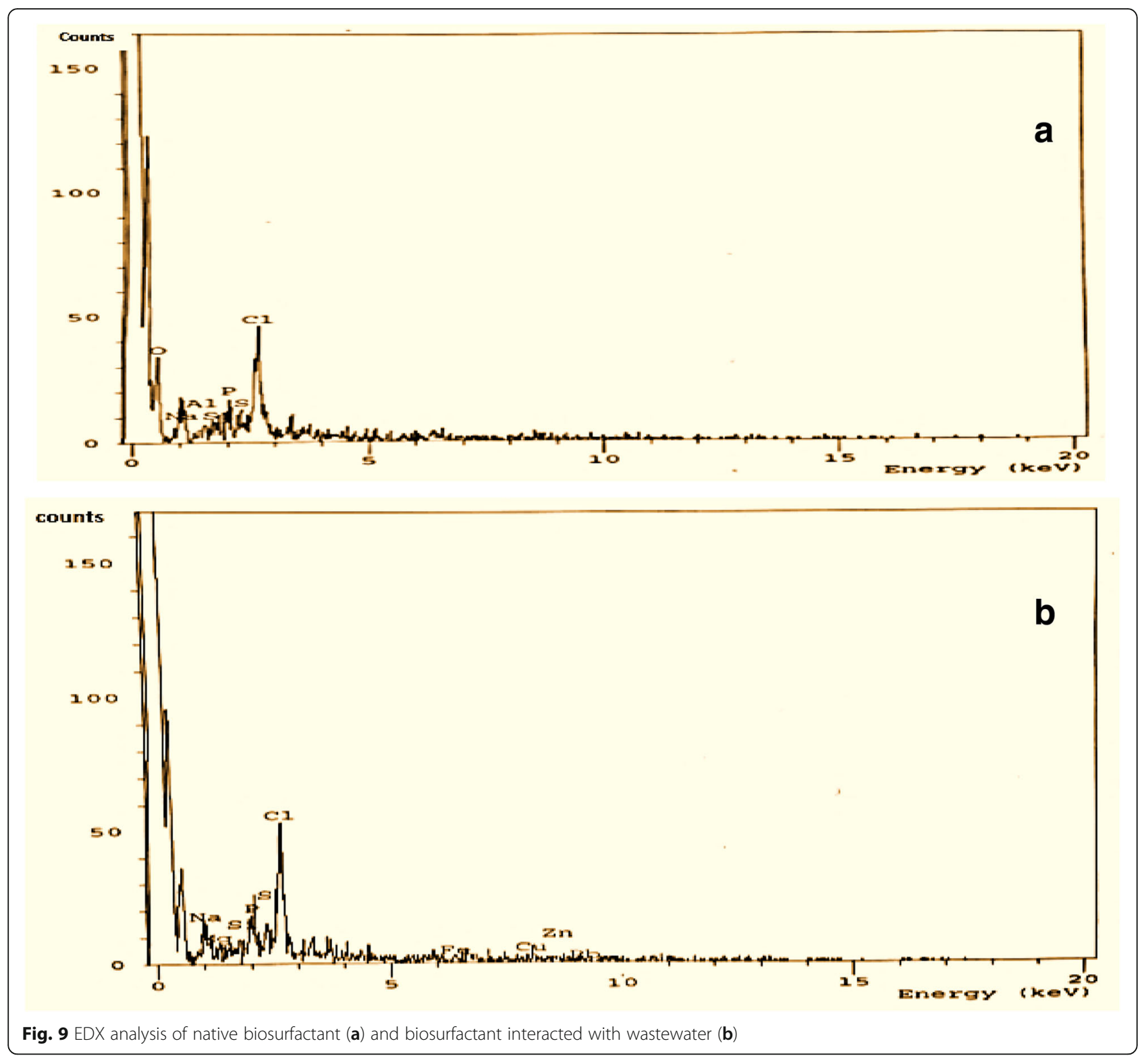

bonds are stronger than the metal's bonds with the soil, and metal-biosurfactant complexes are desorbed from the soil matrix to the soil solution due to the lowering of the interfacial tension. The cationic biosurfactants can replace the same charged metal ions by competition for some but not all negatively charged surfaces (ion exchange). Metal ions can be removed from soil surfaces also by the biosurfactant micelles. The polar head groups of micelles can bind metals which mobilize the metals in water (Diaz et al. 2015).

The superior isolate BS37 showed the highest biosurfactant production and exhibited the greatest heavy metal removal efficiency which was identified according to the morphological and biochemical characterization of colony, and its antibiotic susceptibility were tested. Its identification was accomplished by combining the alignment results of $16 \mathrm{~S}$ rRNA sequence analysis with biochemical and physiological characteristics. The final identification of strain was Citrobacter freundii. Sharma and Fulekar (2009) confirmed this trend of results and documented $C$. freundii as a potential microorganism for remediation of copper. This potential organism can be used for bioremediation of heavy metals to clean up the environment (Macaskie et al. 2006). Additionally, Puranik and Paknikar (2012) and Al-Garni (2005) demonstrated Citrobacter freundii as a bioremoval agent for heavy metals such as lead, cadmium, and zinc from contaminated sites. C. freundii was able to produce biosurfactant using all the tested media, while it was observed 

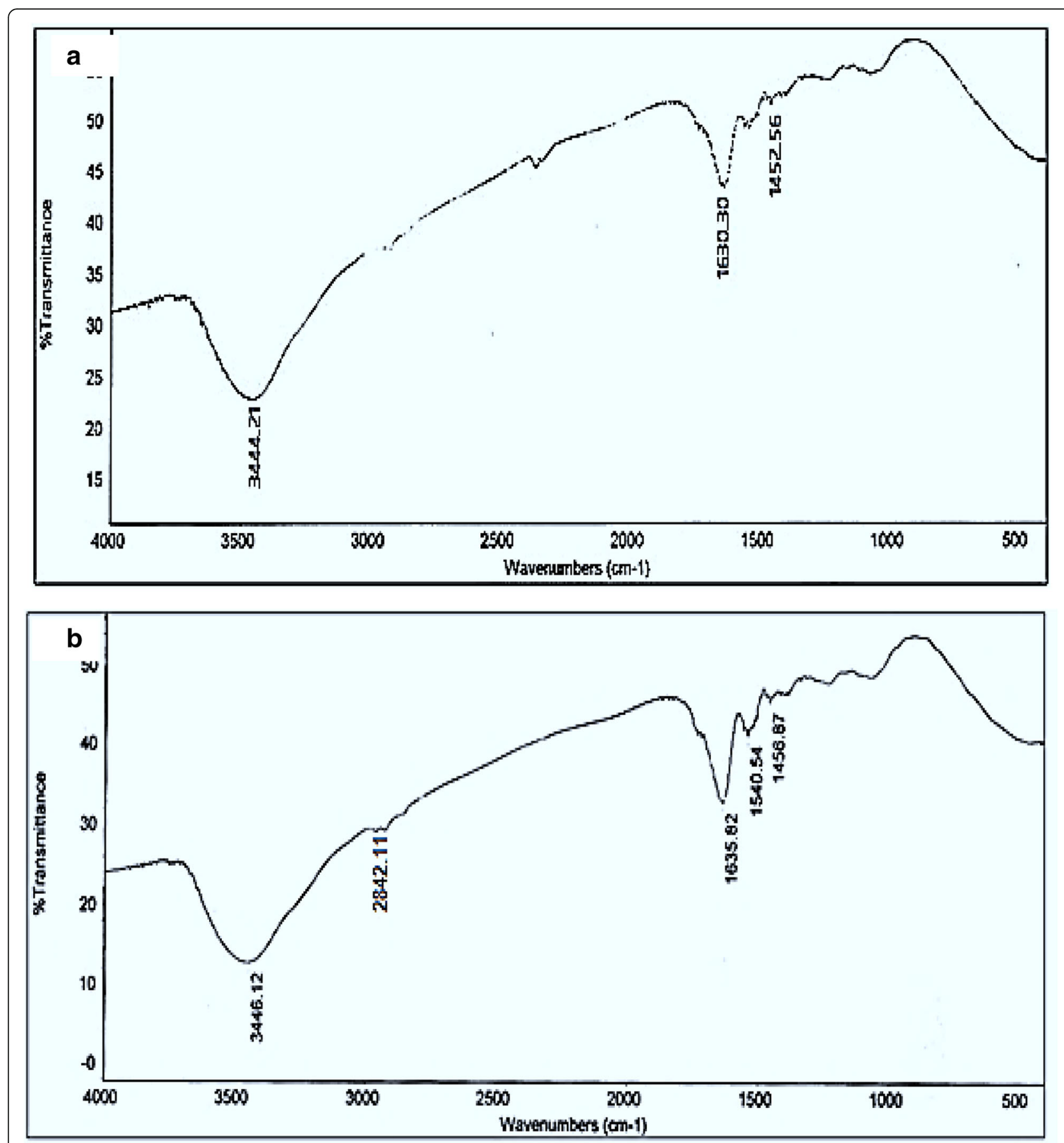

Fig. 10 FTIR spectrum of native biosurfactant (a) and biosurfactant interacted with wastewater (b)

that nutrient broth medium, inoculum potential of $10 \%$, and incubation period of 4 days were found to yield maximal amount of biosurfactant by $C$. freundii MG812314.1. In this regard, Ibrahim (2018) reported that the biosurfactants from $C$. freundii HM-2 were produced in MSM supplemented with 2\% WFO as the sole carbon source; also, this strain was able to produce biosurfactant under different incubation periods $(12,24,36$,
$48,60,72,84,96$ and $108 \mathrm{~h}$ ), and it was found that the production of biosurfactant was gradually increased with the increasing of incubation period until reach maximum at $96 \mathrm{~h}$ then decreased.

From these results, biosurfactant has proven its ability as a washing agent in heavy metal removal, but more information is needed to optimize the process of heavy metal removal (Hidayati et al. 2014). Factors affecting 
the efficiency of the produced bacterial biosurfactant for the removal of heavy metals from wastewater were investigated in this experiment. Results showed that higher removal of heavy metals was recorded when wastewater was treated with biosurfactant at $10 \%$ than $5 \%$. This trend of results was done with all estimated heavy metals. Enhancement of metal remediation capacity with increasing amount of biosurfactant was reported by many researchers (Kim and Vipulanandan 2006; Basak and Das 2014). Results also showed higher removal efficiency with increasing contact time when wastewater was treated with $5 \%$ biosurfactant. In contrast, when treated at $10 \%$, the removal efficiency was decreased with the increasing of the contact time. SEM images showed the morphology of native biosurfactant (Fig. 8a) and the sequestered heavy metals onto biosurfactant (Figs. 8b). The spherical nodules in SEM image (b) confirmed the anchoring of heavy metal ions with biosurfactant molecule. Basak and Das (2014) reported that removal of zinc ion from the aqueous solution was further confirmed using SEM. EDX of native biosurfactant (Fig. 9a) and heavy metals interacted biosurfactant (Fig. 9b) showed that there were constant metals in either native or interacted biosurfactant, viz. $\mathrm{O}, \mathrm{Na}, \mathrm{Al}, \mathrm{P}$, $\mathrm{S}$, and $\mathrm{Cl}$, whereas $\mathrm{Fe}^{2+}, \mathrm{Cu}^{2+}, \mathrm{Zn}^{2+}$, and $\mathrm{Pb}^{2+}$ appeared in interacted biosurfactant with wastewater only. This reflected the efficiency of biosurfactant to absorb heavy metals from wastewater. These results were confirmed by those obtained by Basak and Das (2014) who reported that EDX analysis served as a direct proof of metal attachment to the micellar structure of the biosurfactant. FTIR analysis was performed for confirmation of removal of heavy metals from wastewater. FTIR spectrum of native biosurfactant (Fig. 10a) showed the presence of bands at 3444.21, 1630.30, and 1452.56 $\mathrm{cm}^{-1}$. Moreover, FTIR spectrum showed that the recorded peaks at $3444.21,1630.30$, and $1452.56 \mathrm{~cm}^{-1}$ were shifted respectively to $3446.12,1635.82$, and $1456.87 \mathrm{~cm}^{-1}$. Also, new bands appeared at 2842.11 and $1540.54 \mathrm{~cm}^{-1}$ (Fig. 10b). Similar results were reported by Basak and Das (2014) who recorded bands at 3439.08, 1629.85 , and $1400.32 \mathrm{~cm}^{-1}$ in native biosurfactant produced by Cryptococcus sp. Additionally, Ibrahim (2018) used FTIR analysis to show the relation between the purified biosurfactants and the standard rhamnolipid. The bands recovered at wavenumber $3463 \mathrm{~cm}^{-1}$ and $3457 \mathrm{~cm}^{-1}$ were refer to the $-\mathrm{OH}$ group (free hydroxyl groups of rhamnose rings), while, the bands recovered between 2926 and $2855 \mathrm{~cm}^{-1}$ due to the protraction vibrations of the $-\mathrm{CH}_{2}-$ and $-\mathrm{CH}_{3}$ groups of acyl chains. The bands observed at $2732 \mathrm{~cm}^{-1}$ could be attributed to the $\mathrm{C}-\mathrm{H}$ hydrocarbon chains, while the carbonyl (ester) band was found at $1743 \mathrm{~cm}^{-1}$. Also, the bands observed at 1377 and $1463 \mathrm{~cm}^{-1}$ confirm the presence of alkyl groups. Additionally, he suggested that the bands recorded at $1377 \mathrm{~cm}^{-1}, 2732 \mathrm{~cm}^{-1}$, and $1463 \mathrm{~cm}^{-1}$ may have chemical structures identical to those of glycolipids. The $\mathrm{C}-\mathrm{O}$ stretching bands at 1463 and $1377 \mathrm{~cm}^{-1}$ demonstrated the presence of bonds between the carbon atoms and hydroxyl groups in the chemical structures of the glycoside portion. As compared to previous reports (Lan et al. 2015) these main chemical structure groups were in line with the structure characteristics of rhamnolipid (Ferhat et al. 2011; Noparat et al. 2014; Lan et al. 2015). Spectra analysis of native and interacted biosurfactant clearly indicated that the hydroxyl group $(-\mathrm{OH})$, carboxyl $(-\mathrm{COOH})$, and carbonyl $(\mathrm{C}=\mathrm{O})$ groups were the predominant contributors in heavy metal removal by biosurfactant of $C$. freundii MG812314.1. Similar results were observed by Huang and Liu (2013) who reported the involvement of hydroxyl and carboxyl groups in the removal of cadmium and lead from aqueous solution using bacterial biosurfactants.

\section{Conclusion}

One of the most promising fields of technology is the biological techniques employing biosurfactants as heavy metal removal tools. In the current study, Citrobacter freundii MG812314.1 isolated from Al-Rahawy drain was found to be the most potent biosurfactant producer. The produced biosurfactant exhibited a great capacity to remove the heavy metals depending on the factors like time and concentration of inoculums used. The results opened new perspectives for the use of this strain as a promising biosurfactant producer for efficient heavy metal removal. Further research on structural characterization, gene regulation, and commercial production of biosurfactant is needed to be feasibly used towards in situ bioremediation of industrial wastes.

\section{Acknowledgements}

The authors would like to thank Prof. Hamed E. Abou-Aly professor of

Agricultural microbiology, Department of Agricultural Microbiology, Faculty of Agriculture, Benha University, Egypt for his valuable reviewing this manuscript.

Funding

Not applicable

Availability of data and materials

Data are available upon request from the authors.

Authors' contributions

The both authors contributed to the design and implementation of the research, the analysis of the results, and the writing of the manuscript. Also, both authors read and approved the final manuscript.

Ethics approval and consent to participate

Not applicable

Consent for publication

Not applicable

Competing interests

The authors declare that they have no competing interests. 


\section{Publisher's note}

Springer Nature remains neutral about jurisdictional claims in all publications.

\section{Author details}

'Department of Biological and Geological Sciences, Faculty of Education, Ain Shams University, Cairo, Egypt. ${ }^{2}$ Department of Agricultural Microbiology, Faculty of Agriculture, Benha University, Moshtohor, Benha, Kalyobiya 13736, Egypt. ${ }^{3}$ Microbial Biotechnology and Fermentation Laboratory, Faculty of Agriculture, Benha University, Moshtohor, Benha, Kalyobiya 13736, Egypt.

Received: 13 January 2019 Accepted: 12 March 2019

Published online: 24 April 2019

\section{References}

Abdel-Rahman HM, Salem AA, Moustafa MMA, El-Garhy AS (2017) A novice Achromobacter sp. EMCC1936 strain acts as a plant growth promoting agent. Acta Physiol Plant 39:61-74

Adamu A, ljah UJ, Riskuwa ML, Ismail HY, Ibrahim UB (2015) Study on biosurfactant production by two Bacillus species. Int J Sci Res 3(1):30-20

Al-Garni SM (2005) Biosorption of lead by Gram-ve capsulated and noncapsulated bacteria. Water SA 31(3):345-350

Amiriyan A, Mazaheri AM, Sajadian VA, Noohi AA (2006) Bioemulsan production by Iranian oil reservoirs microorganism. Iran J Env Health Sci Eng Bioresour Technol 97:868-875

Ariech M, Guechi A (2015) Assessment of four different methods for selecting biosurfactant producing extremely halophilic bacteria. Afr J Biotechnol 14(21):17641772

Bachmann RT, Johnson AC, Edyvean RG (2014) Biotechnology in the petroleum industry: an overview. Int Biodeterior Biodegrad 86:225-273

Basak G, Das N (2014) Characterization of sophorolipid biosurfactant produced by Cryptococcus sp. VITGBN2 and its application on Zn (II) removal from electroplating wastewater. J Environ Biol 35:1087-1094

Becker JS (2005) Trace and ultratrace analysis in liquid by atomic spectrometry. Trend Analytical Chem 24(3):243-254

Bertrand H, Nalin R, Bally R, Marel JC (2001) Isolation and identification of the most efficient plant growth promoting bacteria associated with canola. Biol Fert Soil 33:152-156

Chen C, Baker S, Darton R (2007) The application of a high throughput analysis method for the screening of potential biosurfactants from natural sources. J Microbiol Method 70(6):503-510

Diaz MA, de Ranson IS, Dorta BD (2015) Metal removal from contaminated soils through bioleaching with oxidizing bacteria and rhamnolipid biosurfactants. Soil Sed Cont 24:16-29

Duncan DB (1955) Multiple range and multiple F. test. Biometrics 11:11-24

Egypt State of Environment (2015) Ministry of State for Environmental Affairs, Arab Republic of Egypt, part (4): urban environment, chapter (11): urban and Industrial environmental development, pp 287-294

El Bedawy R (2014) Water resources management: alarming crisis for Egypt J Manage Sustain 4(3):108-124

Elazzazy AM, Abdelmoneim TS, Almaghrabi OA (2015) Isolation and characterization of biosurfactant production under extreme environmental conditions by alkali-halo-thermophilic bacteria from Saudi Arabia. Saudi J Bio Sci 22:466-475

Ezzat SM, Mahdy HM, Abo-Astate MA, Abd El-Shakour EH, El-Bahnasawy MA (2012) Water quality assessment of River Nile at Rosetta branch: impact of drains discharge. Middle-East J Sci Res 12:413-423

Ferhat S, Mnif S, Badis A, Eddouaouda K, Alouaoui R, Boucherit A, Mhiri N, Moulai-Mostefa N, Sayadi S (2011) Screening and preliminary characterization of biosurfactants produced by. Ochrobactrum sp. 1C and Brevibacterium sp. $7 \mathrm{G}$ isolated from hydrocarbon-contaminated soils. Int Biodeterior Biodegrad 65:1182-1188

Gautam KK, Tyagi VK (2006) Microbial surfactants: a review. J Oleo Sci 55:155-166 Goher ME, Hassan AM, Abdel-Moniem IA, Fahmy AH, El-Sayed SM (2014) Evaluation of surface water quality and heavy metal indices of Ismailia Canal, Nile River, Egypt. Egypt J Aqua Res 40:225-233

Harrigan WF, MacCance ME (1976) Laboratory methods in food and dairy microbiology. Academic Press, London

Hidayati N, Surtiningsih T, Matuzahroh N (2014) Removal of heavy metals $\mathrm{Pb}, \mathrm{Zn}$ and $\mathrm{Cu}$ from sludge waste of paper industries using biosurfactant. J Bioremed Biodeg 5(7):255-257
Huang W, Liu Z (2013) Biosorption of Cd(II)/Pb(II) from aqueous solution by biosurfactant-producing bacteria: Isothem kinetic characteristics and mechanism studies. Coll Surf B 105:113-119

Hucker GJ, Conn HJ (1923) Methods of Gram staining. Technical Bulletin of the New York state, Agriculture Experimental Station, New York, p 93

Ibrahim HM (2018) Characterization of biosurfactants produced by novel strains of Ochrobactrum anthropi HM-1 and Citrobacter freundii HM-2 from used engine oil-contaminated soil. Egypt J Petrol 27(1):21-29

Janda JM, Abbott SL, Cheung WK, Hanson DF (1994) Biochemical identification of citrobacteria in the clinical laboratory. J Clinc Microbiol 32(8):1850-1854

Kim J, Vipulanandan C (2006) Removal of lead from contaminated water and clay soil using biosurfactants. J Environ Eng 132:777-786

Lan G, Fan Q, Liu Y, Chen C, Li G, Liu Y, Yin X (2015) Rhamnolipid production from waste cooking oil using Pseudomonas SWP-4. Biochem Eng J 101:44-54

Lazarkevich I, Sotirova A, Avramova T, Stoitsova S, Paunova-Krasteva T, Galabova D (2015) Antibacterial activity of methyltiosulfonate and its complexes with rhamnolipid and trehalose lipid against Pseudomonas aeruginosa NBIMCC 1390. Res J Pharm Biol Chem Sci 6:282-290

Luna JM, Rufino RD, Sarubbo LA (2016) Biosurfactant from Candida sphaerica UCP0995 exhibiting heavy metal remediation properties. Process safty Enviro Prot 102:558-566

Macaskie LE, Bonthrone KM, Rouch DA (2006) Phosphatase-mediated heavy metal accumulation by a Citrobacter sp. and related enterobacteria. FEMS Microbiol Letters 121(2):141-146

Matuschek E, Brown DFJ, Kahlmeter G (2014) Development of the EUCAST disk diffusion antimicrobial susceptibility testing method and its implementation in routine microbiology laboratories. Clin Microbiol Infect 20(4):255-266

Morikawa M, Daido H, Takao T, Murata S, Shimonishi Y, Imanaka T (1993) A new lipopeptide biosurfactant produced by Arthrobacter sp. strain MIS 38. J Bacteriol 175:6459-6466

Noparat P, Maneerat S, Saimmai A (2014) Utilization of palm oil decanter cake as a novel substrate for biosurfactant production from a new and promising strain of Ochrobactrum anthropic. World J Microbiol Biotechnol 30:865-877

Patel H, Vashi RT (2010) Treatment of textile wastewater by adsorption and coagulation. J Chem 7(4):1468-1476

Pulsawat W, Leksawasdi N, Rogers PL, Foster LR (2003) Anions effects on biosorption of $\mathrm{Mn}$ (II) by extracellular polymeric substance (EPS) from Rhizobium etli. Biotechnol Lett 25:1267-1270

Puranik PR, Paknikar KM (2012) Biosorption of lead, cadmium, and zinc by Citrobacter strain MCM B-181: characterization studies. Biotech Prog 15(2): 228-237

Rajkumar M, Ae N, Prasad MN, Freitas H (2010) Potential of siderophore producing bacteria for improving heavy metal phytoextraction. Trends Biotech 28:142-149

Ramani K, Jain SC, Mandal AB, Sekaran G (2012) Microbial induced lipoprotein biosurfactant from slaughterhouse lipid waste and its application to the removal of metal ion from aqueous solution. Colloids Surf B 97:254-263

SAS (2004) SAS procedure guide version 6, 12th edn. SAS institute Ine., Cary

Satpute SK, Bhawsar BD, Dhakephalkar PK, Chopade BA (2008) Assessment of different screening methods for selecting biosurfactant producing marine bacteria. Ind J Mar Sci 37:243-250

Sharma J, Fulekar MH (2009) Potential of Citrobacter freundii for bioaccumulation of heavy metal-copper. Biol Med 1(3):7-14

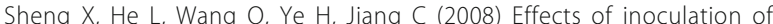
biosurfactant producing Bacillus sp. $J 119$ on plant growth and cadmium uptake in a cadmium-amended soil. J Hazard Mat 155:1722

Singh P, Cameotra SS (2013) Efficiency of lipopeptide biosurfactants in removal of petroleum hydrocarbons and heavy metals from contaminated soil. Environ Sci Pollut Res 20:7367-7376

Sneha C (2012) Bacterial biosurfactant: characterization, antimicrobial and metal remediation properties, M.Sc. thesis in life science. Nat Ins Technol Rourkela, Odisha

Suganya RS (2013) Screening optimization and production of biosurfactants from Bacillus and Pseudomonas species. Int J Cur Pharm Res 5(1):10-23

Thernmozhi R, Sornalaksmi A, Praveenleumar D, Nagasathya A (2011) Characterization of biosurfactant produced by bacterial isolates from engine oil contaminated soil. Adv Environ Biol 5(8):2402-2408

Vijayanand S, Divyashree M (2015) Bioremediation of heavy metals using biosurfactant producing microorganisms. Int J Pharm Sci Res 6(5):840-847 
Wolters W, Smit R, Nour El-Din M, Ahmed S, Froebrich J, Ritzema H (2016) Issues and challenges in spatial and temporal water allocation in the Nile delta. Sustainability 8(383):1-12

Youssef NH, Duncana KE, Naglea DP, Savagea KN, Knappb RM, Mclnerney MJ

(2004) Comparison of methods to detect biosurfactant production by diverse microorganisms. J Microbiol Method 56:339-347

Submit your manuscript to a SpringerOpen ${ }^{\mathcal{O}}$ journal and benefit from:

- Convenient online submission

- Rigorous peer review

- Open access: articles freely available online

- High visibility within the field

- Retaining the copyright to your article

Submit your next manuscript at $\boldsymbol{\sim}$ springeropen.com 